\title{
IMPLEMENTASI KEBIJAKAN PARIWISATA BERBASIS KEARIFAN LOKAL (STUDI DI KABUPATEN MANGGARAI BARAT)
}

\author{
Maksimilianus Maris Jupir \\ Fakultas Ilmu Administrasi Publik Universitas Brawijaya Malang, Indonesia
}

\begin{abstract}
Abstrak
Pergeseran episentrum kekuasaan pasca reformasi tahun 1998 dari sentralistik ke desentralisasi memberi harapan baru kepada setiap daerah untuk membangun daerah dengan segala potensi yang dimiliki. Desentralisasi memberi legitimasi kepada setiap daerah untuk memproduksi atau menghasilkan berbagai kebijakan yang sesuai dengan kebutuhan daerah, termasuk di bidang pariwisata. Sebagai subordinat dari Negara Kesatuan Republik Indonesia, Pemerintah Daerah Kabupaten Manggarai Barat juga memiliki legitimasi yang sama untuk membuat berbagai kebijakan termasuk di bidang pariwisata. Pemerintah Kabupaten Manggarai Barat telah menetapkan pariwisata sebagai leading sector pembangunan dan membuat Kebijakan Pariwisata Berbasis Kearifan Lokal untuk mendukung pengembangan pariwisata. Penelitian ini dilakukan dengan menggunakan metode penelitian kualitatif dengan pendekatan fenomenologi untuk menggambarkan, menganalisis dan menginterpretasikan sisi-sisi implementasi seperti Partisipasi, Jejaring, Struktur Keorganisasian, aktor, finansial, fasilitas, kondisi sosial, budaya, ekonomi dan politik serta kepentingan stakeholder. Teori yang digunakan untuk melakukan kajian ini adalah teori implementasi kebijakan Edward III. Berdasarkan teori ini, kesuksesan implementasi Kebijakan ditentukan oleh empat faktor, yaitu komunikasi, sumber daya, disposisi dan struktur birokrasi. Hasil penelitian menunjukkan bahwa ketersediaan sumber daya pendukung implementasi belum dialokasikan dengan jelas, komunikasi dan koordinasi belum berjalan optimal, kondisi eksternal (sosial, ekonomi, dan politik) menghambat implementasi kebijakan Pariwisata Berbasis Kearifan Lokal di Kabupaten Manggarai Barat secara efektif dan optimal. Implikasinya adalah aktivitas pariwisata berbasis kearifan lokal belum berkontribusi secara optimal bagi pemerintah, swasta dan masyarakat dari sisi ekonomi.
\end{abstract}

Kata Kunci: Kebijakan Publik, Implementasi Kebijakan Publik, Pariwisata, Kearifan Lokal

\begin{abstract}
The Shift epicenter of power after the 1998 reform from centralized to decentralized gives new hope to each region to develop the area with all its potential. Decentralization gives legitimation to each region for product or make various policy matching with requirement of each area, including in tourism sector. West Manggarai Regency has tourism as leading sector in development. For supporting tourism as sector leading for development, West Manggarai Regency has made Policy of Tourism Based on Local Wisdom. This research is done by using qualitative research method with phenomenological approach to describe, to analyze and to interpret the sides of implementation, like participation, network, organizational structure, actor, financial, facility, condition of social, cultural, politics and economics and stakeholder's interest also. The theory is used to conduct this study is the theory of policy implementation of Edward III. According to this theory, the successfull of policy implementation is determined by four factors are communication, resource, bureaucracy structure and disposition. Result of research shows that the availability of the supporting resources have not been allocated clearly, the coordination and communication is not run optimally, the external condition (social, economic, politic) are often the bottleneck to realization Tourism policy Implementation Based on Local Wisdom at West Manggarai Regency effectively and optimally. As a result, the activity of tourism based on local wisdom doesn't give significant benefit for government, private sector and civil society of economic, social, political and cultural side.
\end{abstract}

Keywords: Public Policy, Implementation of Public Policy, Tourism, Local Wisdom.

\section{PENDAHULUAN}

Pariwisata sudah diakui sebagai industri terbesar abad ini, dilihat dari berbagai indikator, seperti sumbangan terhadap pendapatan dunia dan penyerapan tenaga kerja. Cohen [17]

\footnotetext{
Corresponding Address:

Maksimilianus Maris Jupir

Email : jupiracik@yahoo.co.id

Address : Fakultas Ilmu Administrasi Publik, Universitas Brawijaya Malang, Jl. Veteran, Malang
}

mengategorikan dampak pariwisata di bidang ekonomi, antara lain adalah dampak terhadap devisa, pendapatan masyarakat, kesempatan kerja, harga, distribusi manfaat, kepemilikan dan kontrol; pembangunan dan pendapatan pemerintah. Bahkan pada beberapa daerah pariwisata mampu mendongkrak daerah tersebut dari keterbelakangan menjadi sumber pendapatan utama seperti yang terjadi di Bali. Baiquini $d k k$ [2] mengatakan bahwa "pariwisata berperan signifikan dan telah mampu menjadi 
penggerak roda perekonomian masyarakat Bali. Sekitar $80 \%$ dari seluruh masyarakat Bali, kehidupannya tergantung pada pariwisata".

Dengan menggunakan alur logika yang sama, Kabupaten Manggarai Barat yang terbentuk berdasarkan UU Nomor 8 Tahun 2003 dengan ibu kota Labuan Bajo mengedepankan pariwisata sebagai leading sector (sektor utama) pembangunan dalam rangka menyejahterakan masyarakat setempat. Keputusan menetapkan pariwisata sebagai sektor utama dalam pembangunan tentu dilandasi oleh beberapa pertimbangan, antara lain adalah letak Kabupaten Manggarai Barat secara geografis sangat berdekatan dengan Bali, daerah tujuan wisata utama dan pintu masuk utama bagi propinsi Nusa Tenggara Timur dan Flores pada khususnya. Pertimbangan dari segi geografis menjadi satu sisi yang penting bagi penentuan suatu destinasi, akan tetapi itu tidak menjadi faktor determinan. Penentuan pariwisata sebagai sektor unggulan dalam pembangunan di Kabupaten Manggarai Barat tentu berangkat dari kenyataan-kenyatan lain seperti: (a) adanya satwa langka, Varnus Komodoensis yang menjadi ikon pariwisata eksklusif (b) Alam yang eksotis, (c) Kekayaan bahari, dan (d) Kearifan budaya lokal yang menarik dan sejarah yang mengesankan. Kesadaran akan banyaknya aset pontensial yang demikian menjadikan Kabupaten Manggarai Barat memproritaskan pariwisata sebagai fudamental pembangunan. Akan tetapi, realitas empiris menunjukkan bahwa masyarakat tidak secara optimal meraup manfaat dari keberadaan aset potensial pariwisata yang ada. Hal ini tercermin dari masih tingginya angka kemiskinan di Kabupaten Manggarai Barat.

Salah faktor pemicu terjadi kekosongan peran pariwisata sebagai lokomotif pembangunan di Kabupaten Manggarai Barat disebabkan karena aset-aset potensial penopang pengembangan pariwisata belum seluruhnya dimaksimalkan pemanfaatannya. Sebagai salah satu daerah tujuan pariwisata, Kabupaten Manggarai Barat memang sudah dikenal baik oleh wisatawan dalam dan luar negeri dengan adanya Komodo. Akan tetapi, pariwisata di Kabupaten Manggarai Barat tidak hanya bergantung pada kepopuleran kadal raksasa tersebut, masih terdapat aset potensial lainnya yang bisa menjadi fundamen bagi pembangunan pariwisata. Aset tersebut antara lain adalah kearifan lokal masyarakat setempat. Sebab apabila kearifan lokal direvitalisasi dengan baik, itu akan menjadi daya tarik tersendiri bagi pengembangan pariwisata di
Kabupaten Manggarai Barat. Keunikan kebudayaan tersebut termanifestasi dalam beragam bentuk antara lain adalah pengetahuan setempat, sistem kepercayaan, ritual budaya dan kesenian. Warisan budaya tersebut hendaknya diemban dengan berbagai upaya pelestarian serta pemanfaatan yang positif. Aktivitas pariwisata berbasis pada kearifan lokal tentu saja tidak berdiri terpisah dari nuansa budaya yang melingkupinya dan melekat pada suatu komunitas tertentu. Tidak ada pariwisata tanpa budaya, artinya apabila sebuah daerah mempromosikan pariwisata pada dasarnya yang dipromosikan adalah budaya di sebuah destinasi tersebut. Pitana dan Gayatri (2005: 96) mengatakan bahwa "kebudayaan merupakan sumber daya yang menjadi modal bagi pariwisata itu sendiri" [17].

Budaya dalam beragam manifestasinya menjadi daya tarik dan pendorong bagi wisatawan yang berkunjung ke suatu tempat dan menjadi objek konsumtif yang menarik di bidang pariwisata karena di dalamnya mengadung pengalaman (experience). Suweda dan Widyatmaja (2010: 89) mengatakan bahwa "atraksi wisata budaya seperti arsitektur rumah tradisional di desa, situs arkeologi, benda-benda seni dan kerajinan, ritual dan upacara budaya, festival budaya, kegiatan dan kehidupan masyarakat sehari-hari, keramahtamahan, makanan dan lain-lain merupakan daya tarik bagi wisatawan" [23]. Dengan demikian, yang dimaksud dengan kebijakan pariwisata berbasis kearifan lokal adalah kebijakan di bidang pariwisata yang mengedepankan segala bentuk keunikan yang dimiliki oleh suatu komunitas atau daerah tertentu yang mengandung nilai-nilai kebudayaan baik yang bersifat material maupun non-material.

Akan tetapi, realitas empiris pariwisata yang beroperasi di Kabupaten Manggarai Barat belum mampu berperan optimal dalam menopang pembangunan walaupun terdapat banyak program ataupun kekayaan aset pontensial bagi pengembangan pariwisata berbasis kearifan lokal. Hal ini menggambarkan adanya pengimplementasian yang problematis, sehingga pariwisata terkesan hanya terpampang sebatas keindahan eksotik secara defenitif di ruang publik, yakni kehadiran pariwisata dimaknai sebatas keindahan semata yang tidak berpengaruh terhadap sektor-sektor yang lain dan bergerak pada pseudo (semu) profit buat masyarakat setempat. Minimnya peran positif dari keberadaan kebijakan pariwisata berbasis kearifan lokal merupakan reflektif dari ketidakefektifan 
kebijakan tersebut pada tataran implementasi. Ketidakefektifan implementasi kebijakan tersebut berakar pada hambatan-hambatan yang bervariasi.

\section{Landasan Normatif Kebijakan Pariwisata Berbasis Kearifan Lokal}

Kekayaan kearifan lokal tersebut menjadikan Kabupaten Manggarai Barat menjadi salah satu daerah tujuan wisata yang paling dimintai di Propinsi Nusa Tenggara Timur (NTT). Untuk mendukung pariwisata berbasis kearifan lokal tersebut, Kabupaten Manggarai Barat dalam narasi besar telah memasukkan itu dalam strategi kebijakan pariwisatanya, walaupun dampaknya masih belum signifikan. Kebijakan Pariwisata Berbasis Pada Kearifan Lokal di Kabupaten Manggarai Barat merujuk pada undang-undang (UU) Nomor 10 Tahun 2009 Pasal 5 Ayat 2 Tentang Prinsip Penyelenggaraan Pariwisata harus menjunjung tinggi hak asasi manusia, keberagaman budaya, dan kearifan lokal dan UU Nomor 25 Tahun 2000 Tentang Program Pembangunan Nasional (PPN) dilevel daerah, kebijakan pariwisata berbasis kearifan lokal terakomodasi dalam Rancangan Induk Pengembangan Pariwisata Daerah (RIPPDA) Kabupaten Manggarai Barat Tahun 2008, Visi dan Misi Kabupaten Manggarai Barat periode 20102015 dan Rencana Strategis (Renstra) Dinas Kebudayaan dan Pariwisata Kabupaten Manggarai Barat Tahun 2011-2015 [25][26].

\section{METODE PENELITIAN}

Penelitian ini dilakukan dengan menggunakan metode penelitian kualitatif dengan pendekatan fenomenologi. Menurut Creswell (2009: 13) phenomenological research is a strategy of inquiry in which the researcher indentifies the essence of human experinces about phenomenon as described by participants [13]. Pendekatan fenomenologi digunakan untuk mengungkapkan bagaimana Implementasi Kebijakan Pariwisata Berbasis Kearifan Lokal di Kabupaten Manggarai Barat berjalan.

\section{a) Lokasi Penelitian}

Penelitian ini mengambil lokasi di Kabupaten Manggarai Barat. Alasan pemilihan daerah ini didasari oleh alasan berikut ini:

1) Kabupaten Manggarai Barat merupakan salah satu Daerah Tujuan Wisata (DTW) di Propinsi Nusa Tenggara Timur yang kaya dengan keragaman budaya lokal, yang bisa dijadikan sebagai tulang punggung pembangunan.
2) Terdapat format kebijakan pariwisata berbasis kearifan lokal yang implementasinya belum dilaksanakan secara optimal.

3) Akses peneliti ke sumber data (para pejabat pemeritahan, masyarakat, dan pelaku-pelaku pariwisata) di Kabupaten Manggarai Barat cukup baik, sehingga peneliti tidak mengalami kesulitan berarti untuk mendapatkan data dan informasi selama penelitian berlangsung.

\section{b) Situs Penelitian}

Situs penelitian adalah tempat dimana penelitian mengumpulkan data yang sebenarnya dari objek yang diteliti. Oleh karena itu, yang menjadi situs dalam penelitian ini adalah Dinas Kebudayaan dan Pariwisata (Disbudpar) Kabupaten Manggarai Barat yang terdiri dari pegawai-pegawai struktural yang ada di dalamnya dan semua orang yang terlibat (Pengembang, Pelestari, dan Pelaksana Nilai-nilai Kearifan Lokal) di dalam aktivitas Pariwisata Berbasis Kearifan Lokal di Kabupaten Manggarai Barat.

\section{c) Teknik Pengumpulan Data}

Newman (2000: 145) mengatakan "qualitative data are empirical (data kualitatif merupakan empiris). They involve documenting real events, recording what people say (with words, gestures, and tone), observing specific behaviors, studying written document, or examining visual images" Oleh karena data dalam penelitian kualitatif adalah data empiris, maka pengumpulan data pun bergerak dari lapangan empiris untuk memperoleh data dan teori.

\section{d) Teknik Pengumpulan Data}

Newman (2000: 145) mengatakan "qualitative data are empirical (data kualitatif merupakan empiris). They involve documenting real events, recording what people say (with words, gestures, and tone), observing specific behaviors, studying written document, or examining visual images" Oleh karena data dalam penelitian kualitatif adalah data empiris, maka pengumpulan data pun bergerak dari lapangan empiris untuk memperoleh data dan teori [11].

\section{e) Analisis dan Interpretasi Data}

Analisis dan interpretasi data dalam penelitian ini menggunakan analisis Multiple Levels of Analisis dari Cresswell. Cresswell (2009: 183) mengatakan bahwa "the process of data analysis invoves making sense out of 
text anda image data. It involves preparing the data for analysis, conducting different analysis, moving deeper and deeper into understanding the data (some qualitative researcher like to think of this as peeling back the layers of a nonion), representatif the data, and making an interpretation of the larger meaning of the data" [3].

\section{HASIL DAN PEMBAHASAN}

Implementasi Kebijakan Pariwisata Berbasis Kearifan Lokal di Kabupaten Manggarai Barat ditilik dari beberapa segi, yaitu partisipasi masyarakat (Pengembang, Pelestarian dan Pelaksanaan) Kearifan Lokal, Struktur Kelembagaan Dinas Kebudayaan dan Pariwisata Kabupaten Manggarai Barat, Pengalokasian Sumber daya (aktor, finansial, organisasi, fasilitas), komunikasi dan koordinasi; kondisi sosial, ekonomi dan politik, serta kepentingan dari stakeholder.

1) Partisipasi Masyarakat

Partisipasi masyarakat Kabupaten Manggarai Barat di dalam aktivitas pariwisata dapat ditilik dari tiga segi, yakni pengembangan, pelestarian, dan pelaksanaan nilai-nilai kearifan lokal.

a. Partisipasi Dalam Pengembangan Kearifan Lokal

Pengembangan Pariwisata Berbasis Kearifan Lokal di Kabupaten Manggarai Barat masih diwarnai oleh dominasi pemerintah daerah semata. Bentuk partisipasi konsultatif, pasif dan mengalir dari atas. Hal ini tercermin dari penyusunan Rancangan Induk Pengembangan Pariwisata Daerah (RIPPDA) Tahun 2008 yang hanya melibatkan dua sektor, yakni pemerintah daerah yang diwakili oleh Dinas Kebudayaan dan Pariwisata dan Universitas Erlangga Surabaya.

Hal lain yang menunjukkan kentalnya dominasi Pemerintah Daerah Kabupaten Manggarai Barat dalam aktivitas pariwisata tercermin dari program-program yang dicanangkan. Program-program tersebut antara lain adalah sebagai berikut:

a. Peningkatan kesadaran dan pemahaman masyarakat terhadap keragaman budaya

b. Peningkatan apresiasi terhadap nilai-nilai kebudayaan.

Untuk mencapai sasaran tersebut, Kabupaten Manggarai Barat melalui Dinas Kebudayaan dan Pariwisata melakukan beragama kegiatan sebagai berikut:

a. Pentas rutin dan parodi kebudayaan b. Perekaman suara dan gambar (mbata, sanda, danding, dan korong)

c. Dokumentasi musik

d. Pagelaran budaya

e. Seminar tentang kebudayaan

f. Pelatihan musik dan tari tradisional

g. Revitalisasi lembaga-lembaga adat

h. Pembentukan dewan kesenian daerah dan Pelestarian produk-produk kebudayaan.

b. Partisipasi Dalam Pelestarian Nilai Kearifan Lokal

Darmawan (2010: 157) mengatakan bahwa tokoh masyarakat, paling tidak dapat menjalankan fungsi pemeliharaan budaya, fungsi integrasi, dan fungsi pencapaian tujuan. Kamus Bahasa Indonesia (Pusat Bahasa Departemen Pendidikan Nasional, 2008: 1536) mendefinisikan tokoh sebagai "orang yang terkemuka dan kenamaan di bidang politik, kebudayaan atau pemegang peran utama". Jadi, tokoh masyarakat dapat pula diartikan sebagai individu yang terkemuka di bidang politik dan budaya yang ada di tengah masyarakat. Bersandar pada pemahaman tersebut, upaya pelestarian Kearifan Lokal yang ada di Kabupaten Manggarai Barat dilaksanakan oleh tokoh-tokoh masyarakat yang ada di sana. Ahmad (Darmawan, 2010: 159) mengatakan wujud konkret dari peran yang dapat dimainkan oleh tokoh masyarakat tersebut antara lain adalah menginventarisasi kembali nilai-nilai itu, memahami, mengajarkan dan mempraktekkannya dalam kehidupan. Sejalan dengan pemehaman tersebut, upaya pelestarian Kearifan Lokal di Kabupaten Manggarai Barat dilakukan dari generasi tua, terutama dari tokoh-tokoh adat, seperti Tu'a Golo, Tu'a Teno, dan Tu'a Pangga. Upaya pelestarian Kearifan Lokal di Kabupaten Manggarai Barat juga bekerjasama dengan Dr. Jeanine Pfeiffer dalam Program Pelestarian Budaya dan Ekologi Tado, The Tado Cultural Ecology Convervation Program (TCECP) yang berupaya untuk mengembangkan desa wisata di Tado. Inti program ini adalah menyadarkan masyarakat Tado, bahwa mereka sendiri yang bertanggung jawab sepenuhnya untuk pelestarian dan pemulihan tradisi budaya dan ekologi yang mendasari keunikan mereka sebagai manusia.

c. Partisipasi Dalam Pelaksanaan Nilai-nilai Kearifan Lokal

Selain itu, secara natural sebagaimana yang diwariskan secara turun-temurun, tokoh- 
tokoh adat seperti Tu'a Golo, Tu'a Teno, dan Tu'a Pangga juga ikut terlibat dalam pelaksanaan nilai-nilai Kearifan Lokal yang ada di Kabupaten Manggarai Barat. Keterlibatan tokoh-tokoh adat tersebut sebagai pelaksaan nilai-nilai kearifan lokal karena merekalah yang memegang peranan penting di dalam upacaraupacara ataupun ritual adat, seperti Caci ataupun Penti. Tokoh-tokoh adat tersebut tersebar merata di seluruh wilayah administratif Kabupaten Manggarai Barat.

2) Jejaring Yang Mempromosikan Pariwisata Kearifan Lokal

Pengembangan Pariwisata Berbasis Kearifan Lokal di Kabupaten Manggarai Barat tentu saja membutuhkan penataan yang baik dan dukungan finansial yang mumpuni. Penataan yang baik dilakukan melalui upaya-upaya promosi yang intensif yang dilakukan dengan berbagai jaringan baik individu maupun dengan kelompok tertentu. Secara institusional, program untuk mempromosikan kearifan lokal tetap menjadi domain pemerintah melalui Dinas Kebudayaan dan Pariwisata Kabupaten Manggarai Barat. Program yang dilakukan oleh Dinas Kebudayaan dan Pariwisata dalam meningkatkan promosi Pariwisata Berbasis Kearifan Lokal di Kabupaten Manggarai Barat adalah sebagai berikut:

a. Pagelaran Seni dan Budaya FloresLembata

b. Pembinaan dan pengiriman duta kebudayaan tingkat nasional

c. Pengiriman seniman untuk mengikuti diklat penataan tari/ koreografi tingkat propinsi.

Akan tetapi, kegiatan yang dicanangkan oleh Dinas Kebudayaan dan Pariwisata Kabupaten Manggarai Barat sebagian besar hanya berada di atas blue-print semata. Aktivitas nyata dari kegiatan tersebut tidak berjalan optimal.

Selain itu, strategi promosi Kearifan Lokal sebagai salah satu aset potensial bagi pengembangan pariwisata di Kabupaten Manggarai Barat masih dilakukan secara simultan dengan upaya-upaya promosi yang berkaitan dengan Komodo. Hal itu tercermin dari slogan pariwisata di Kabupaten Manggarai Barat "Komodo and So Much More". Slogan ini dimaksudkan untuk memperkenalkan Komodo dan Biota bawah laut di dalam TN Komodo sebagai pusat wisata sedangkan obyek wisata alam dan budaya di Kabupaten Manggarai Barat menjadi wisata pendukung.

Upaya promosi Kearifan Lokal di Kabupaten Manggarai Barat juga dilakukan dengan menggunakan media elektronik. Nugroho (2011: 128-129) mengatakan bahwa:

"Media promosi wisata telah berkembang dalam ragam dan kualitas yang relatif tinggi. Media cetak dan offline maupun online setiap saat membatu menemukan tujuan atau produk wisata yang diinginkan. Bagi pengunjung yang telah datangk mereka dapat menjadi media promosi yang efektif untuk menyampaikan kepada keluarga, teman dan kolega" [12].

Dalam kaitannya dengan itu, upaya promosi pariwisata berbasis kearifan lokal di Kabupaten Manggarai Barat sudah dilakukan lewat media elektronik seperti itu. Misalnya seperti yang termuat di dalam website www.floreskomodo.com.

Selain pihak pemerintah, usaha mempromosikan pariwisata di Kabupaten Manggarai Barat dilakukan dengan bekerjasama dengan pihak PT. Sidomuncul. Aksi nyata dari kerjasama tersebut dalam mempromosikan pariwisata di Kabupaten Manggarai Barat tersebut adalah dengan membuat iklan Kuku Bima Energi dengan berlatar belakangkan air terjun Cunca Wulang, Pulau Komodo, Pantai Merah, Takamakasa, spider rice/area persawahan berbentuk jaring laba-laba dengan menelan biaya sebesar Rp. 12 Miliar.

Berangkat dari kondisi tersebut, dapat ditarik suatu kesimpulan bahwa kegiatan-kegiatan dalam rangka meningkatkan promosi Kearifan Lokal di Kabupaten Manggarai Barat sebagai aset potensial pariwisata tidak dilakukan secara rutin dan berkelanjutan. Sehingga dampak yang ditimbulkan dari keberadaan dari pariwisata berbasis kearifan lokal tersebut belum signifikan bagi pemerintah, swasta dan masyarakat sebagai penerima manfaat dari aktivitas tersebut. Peran promosi dalam memperkenalkan kekayaan potensi yang ada di daerah sangat penting untuk menarik minat wisata untuk berkunjung. Widiatedja (2011: 101) mengatakan bahwa "keberadaan aspek promosi memegang peran vital dalam proses pencitraan dan pemasaran suatu produk. Sehebat, seandal, dan seindah apapun kualitas suatu produk akan menjadi tidak berarti apabila tidak didukung oleh upaya promosi yang kreatif dan inovatif" [27]. Lemahnya upaya promosi Pariwisata Berbasis Kearifan Lokal di Kabupaten Manggarai Barat disebabkan karena orientasi pengembangan pariwisata yang ada sampai dengan saat ini tercurah bagi pada pengelolaan TNK (Taman Nasional Komodo) dan 
Batu Cermin. Sedangkan objek dan daya tarik pariwisata yang lain diterlantarkan dan menjadi penempel dari kedua objek dan daya tarik tersebut.

3) Struktur Kelembagaan Dinas Kebudayaan dan Pariwisata Kabupaten Manggarai Barat

Urusan kepariwisataan di Kabupaten Manggarai Barat diserahkan kepada pemerintah semata dengan porsi kewenangan yang berlipat ganda. Berkaca pada realitas yang demikian, sehingga yang menjadi implementator/agensi pelaksana utama dalam Implementasikan Kebijakan Pariwisata Berbasis Kearifan Lokal di Kabupaten Manggarai Barat adalah Dinas Kebudayaan dan Pariwisata setempat. Sebagai agen pelaksana utama, Dinas Kebudayaan dan Pariwisata Kabupaten Manggarai Barat dituntut adanya pembagian tugas dan fungsi yang jelas dari masing-masing unit organisasi demi tercapai tujuan kebijakan tersebut. Berkaitan dengan itu, penataan struktur birokrasi Pemerintah Kabupaten Manggarai Barat mengacu pada peraturan pemerintah (PP) Nomor 8 Tahun 2003 Tentang Pedoman Organisasi Perangkat Daerah yang ditetapkan tanggal 17 Februari 2003. Dalam peraturan pemerintah tersebut dijelaskan bahwa urusan kepariwisataan sepenuhnya diberikan kepada Dinas Kebudayaan dan Pariwisata setempat. Secara historis, Dinas Kebudayaan dan Pariwisata Kabupaten Manggarai Barat terbentuk berdasarkan Peraturan Daerah (Perda) Nomor 03 Tahun 2006. Berdasarkan Peraturan Daerah tersebut, fungsi Dinas Kebudayaan dan Pariwisata adalah membantu Bupati dalam urusan kebudayaan dan pariwisata.

4) Pengalokasian Sumber Daya

a. Aktor

Sebuah kebijakan akan bermanfaat apabila itu telah diimplementasikan dan keberhasilan suatu implementasi kebijakan sangat ditentukan yang terlibat. Idealnya aktor implementasi kebijakan itu mencakup tiga aktor utama, yakni pemerintah (state), swasta (private) dan masyarakat sipil (civil society). Kesemua aktor tersebut berafiliasi pada upaya memajukan dan menyukseskan kebijakan. Untuk mengoptimalkan implementasi kebijakan yang menggunakan pendekatan top-down, maka ketersedian sumber daya implementasi harus mumpuni. Menurut Webber (Kumorotomo, 2009: 77) mengatakan bahwa supaya seseorang dapat bekerja secara efisien, ia harus memiliki keahlian-keahlian tertentu dan menerapkan secara aktif dan rasional. Setiap anggota harus ahli dalam bidang keterampilan tertentu untuk dapat menjalankan tugas yang dibebankan kepadannya.

Model implementasi kebijakan pariwisata yang diterapkan di kabupaten Manggarai Barat menggunakan pendekatan top-down. Penggunaan model implementasi ini didasari oleh situasi riil yang ada di lapangan yang menunjukkan bahwa hampir semua kebijakan di ranah publik didominasi oleh pihak pemerintah semata. Sedangkan keterlibatan aktor di luar pemerintah, terlebih masyarakat masih bersifat pasif. Secara jelas, menurut asas legalitas bupati Kabupaten Manggarai Barat merupakan aktor utama. Namun mengingat peran dan tugas yang sangat luas dari seorang bupati, maka ia mendelegasikan peran tersebut kepada pihak lain dalam hal ini adalah Dinas Kebudayaan dan Pariwisata (Disbudpar) setempat. Sebagai motor penggerak utama dalam mengimplementasikan kebijakan pariwisata berbasis kearifan lokal, Dinas Kebudayaan dan Pariwisata Kabupaten Manggarai Barat bukan tanpa persoalan. Implementasi Kebijakan Pariwisata Berbasis Kearifan Lokal di Kabupaten Manggarai Barat masih ditemui kendala yang bisa menghambat tercapainya tujuan dari kebijakan pariwisata berbasis kearifan lokal. Salah satu kendala yang mencolok adalah belum optimalnya peran aktor yang telah mendapat kewenangan dalam mengatur sektor pariwisata. Hal ini dipicu oleh kekurangan sumber daya secara kualitatif dan kuantitatif sehingga menghambat operasionalisasi kebijakan.

b. Finansial

"Funds still may be required to Guarantee enforcment of the new policy" [5].

Merujuk pada pendapat Gerston di atas, implementasi bukanlah pekerjaan mudah. Kesukaran tersebut bisa berupa terbatasnya persediaan dana yang dibutuhkan dalam melaksanakan program yang telah ditetapkan. Pendanaan merupakan suatu unsur kunci agar suatu keputusan kebijakan dapat berjalan. Wahab (2012) mengatakan "dalam program-program regulatif, dana diperlukan untuk menggaji atau menyewa tenaga personalia, dan untuk memungkinkan dilakukan analisis teknis yang diperlukan untuk membuat peraturan-peraturan, mengadministrasikan program perizinan, dan memonitor pelaksanaannya".

Pendanaan juga merupakan salah satu faktor kunci keberhasilan Implementasi Kebijakan Pariwisata Berbasis Kearifan Lokal di Kabupaten Manggarai Barat. Undang-Undang Pariwisata Nomor 10 Tahun 2009 Pasal 57 berbunyi bahwa "pendanaan pariwisata menjadi tanggunjawab 
bersama Pemerintah, Pemerintah Daerah, Pengusaha, dan Masyarakat". Selain itu, dalam Pasal 59 Undang-undang Pariwisata Tahun 2009 menjelaskan bahwa "Pemerintah Daerah mengalokasikan sebagian dari pendapatan yang diperoleh dari penyelenggaraan pariwisata untuk kepentingan pelestarian alam dan budaya". Konsep ideal dalam mendanai aktivitas pariwisata sebagaimana tertera pada UU tersebut tidak berjalan optimal. Selama ini, sumber pendanaan utama bagi pengembangan pariwisata berasal dari Dinas Kebudayaan dan Pariwisata Kabupaten Manggarai Barat dan Anggaran Pendapat dan Belanja Daerah (APBD) Kabupaten Manggarai Barat. Tapi di sisi lain, kemampuan APBD Kabupaten Manggarai Barat yang serba terbatas, tidak bisa menyanggupi semua kebutuhan anggaran yang diajukan oleh Dinas Kebudayaan dan Pariwisata. Penyebab utama terbatasnya jumlah alokasi anggaran yang dialokasikan untuk Dinas Kebudayaan dan Pariwisata disebabkan karena arah kebijakan Pemerintah Kabupaten Manggarai Barat masih memfokuskan pada pembangunan infrastruktur. Sama seperti daerah lain di Indonesia, sebagai suatu kabupaten yang relatif baru, pembangunan infrastruktur menjadi primadona. Pembangunan infrastruktur yang terus digenjot tentu saja membutuhkan dana besar dan tentu saja hampir semua anggaran yang dimiliki dialokasikan bagi pembangunan infrastruktur.

c. Fasilitas

Sumber daya peralatan merupakan sarana yang digunakan untuk operasionalisasi suatu kebijakan yang meliputi gedung, tanah, dan sarana penunjang lainnya. Berhasil atau tidaknya suatu implementasi kebijakan ditentukan oleh ketersediaan fasilitas penunjang yang ada. Apabila fasilitas yang tersedia kurang memadai, maka hal tersebut dapat berpengaruh terhadap kesuksesan implementasi kebijakan. Keterkaitan antara fasilitas dan kesuksesan implementasi diutarakan oleh Edward III yang mengatakan "physical facilities may also be critical resources in implementation. An implementator may have sufficient staff, may understand what he is supposed to do, may have authority to exercise his task, but without the necessary building, equipment, supplies, and even green space implementation won't succed [28]. Dengan demikian, korelasinya adalah terbatasnya fasilitas yang tersedia tidak bisa menunjang efisiensi dan tidak mendorong motivasi dari agen pelaksana dalam menjalankan tugas demi mencapai tujuan yang diharapkan.
Sebagai implementator utama dari setiap kebijakan ataupun program yang berkaitan dengan pariwisata di Kabupaten Manggarai Barat, Dinas Kebudayaan dan Pariwisata Kabupaten Manggarai Barat masih dihadapkan pada terbatasnya fasilitas pendukung pelaksanaan. Kondisi tersebut berimplikasi negatif terhadap kinerja yang ditunjukkan oleh instansi tersebut dalam melaksanakan berbagai program ataupun kebijakan yang telah ditetapkan. Seringkali keterbatasan fasilitas penunjang implementasi kebijakan tersebut dijadikan alibi oleh implementator apabila tujuan kebijakan pariwisata tidak tercapai.

5) Komunikasi dan koordinasi

Garis koordinasi dan komunikasi antar agen pelaksana merupakan hal yang substantif dalam mendukung kesuksesan implementasi kebijakan. Pentingnya koordinasi dan komunikasi ditegaskan oleh Hogwood dan Gunn yang mengatakan bahwa komunikasi adalah perekat organisasi, dan koordinasi adalah asal-muasal dari kerja sama tim serta terbentuknya sinergi [12]. Garis komunikasi dan koordinasi adalah hal vital bagi keberhasilan suatu implementasi kebijakan. Melalui proses komunikasi yang intensif, para pelaku kebijakan yang teridentifikasi dalam struktur birokrasi menjadi jelas (clarity) apa yang menjadi substansi kebijakan, mencakup apa yang menjadi tujuan, sasaran dan arah kebijakan. Perlu disadari bahwa agen implementasi bukanlah terdiri dari aktor tunggal semata, melainkan bervariasi. Semakin banyak pihak yang terlibat, semakin besar kemungkinan munculnya masalah komunikasi dan koordinasi bahkan kompetisi di antara mereka [21].

Kabupaten Manggarai Barat telah memproklamirkan bahwa pariwisata merupakan leading sector pembangunan. Untuk mencapai harapan sebagai leading sector tentu saja dibutuhkan kerjasama semua pihak, baik itu pemerintah, swasta dan masyarakat. Untuk menjembatani kerjasama dari ketiga aktor kunci dalam aktivitas tersebut dibutuhkan suatu model komunikasi dan koordinasi intensif. Titik acuan pentingnya koordinasi dan komunikasi dalam Implementasi Kebijakan Pariwisata Berbasis Kearifan Lokal di Kabupaten Manggarai Barat didasari oleh beberapa pertimbangan sebagai berikut:

a. Struktur dan kompleksnya organisasi di Dinas Kebudayaan dan Pariwisata Kabupaten Manggarai Barat yang menyebabkan rentang kendali (span of control) menjadi susah. 
b. Adanya pembagian tugas di setiap unit dengan tingkat spesialisasi tertentu.

c. Urusan Pariwisata Berbasis Kearifan Lokal di Kabupaten Manggarai Barat tidak semata didominasi oleh Dinas Kebudayaan dan Pariwisata, tetapi juga berkaitan dengan instansi-instansi lain seperti Dinas Pekerjaan Umum, Dinas Perindustrian maupun Dinas Perhubungan.

Oleh karena itu, untuk mencegah terjadinya ketidakserasian, tumpang tindih ataupun konflik antara unit ataupun antara instansi yang satu dengan yang lain, maka diperlukan suatu bentuk komunikasi demi keterpaduan kerja tim guna menyelaraskan setiap aktivitas dari unit-unit organisasi ke arah pencapaian tujuan kebijakan yang ada. Komunikasi dan koordinasi di Dinas Kebudayaan dan Pariwisata Kabupaten Manggarai Barat diatur dalam Peraturan Pemerintah (PP) Nomor 8 Tahun 2003 Tentang Organisasi Perangkat Daerah (OPD). Berdasarkan PP tersebut, dalam rangka membangun komunikasi dan koordinasi lintas sektoral didelegasikan kepada Seksi Kerjasama dan Hubungan Antar Lembaga. Selama ini, kerjasama lintas sektoral di Kabupaten Manggarai Barat tidak semulus yang berada di atas kertas. Hal ini disebabkan karena ego sektoral yang masih sangat kental.

Selain kerjasama dengan lintas sektoral dalam instansi pemerintah yang ada, di dalam Satuan Kerja Perangkat Daerah (SKPD) kerjasama dengan aktor atau institusi non-negara juga dilakukan oleh Dinas Kebudayaan dan Pariwisata. Misalnya Jalinan kerjasama dengan HPI (Himpunan Pramuwisata Indonesia), ASITA (Association of Indonesia Tours and Travel Agencies), dan PHRI (Perhimpunan Hotel dan Restoran Indonesia). Akan tetapi, konkret dari kerjasama dengan berbagai lembaga tersebut tidak pernah dijabarkan dengan jelas sampai dengan hari ini.

6) Kondisi Sosial, Ekonomi, dan Politik

a. Kondisi Sosial

Lingkungan sosial turut mempengaruhi suatu kebijakan implementatif atau tidak. Kondisi sosial yang dimaksudkan di sini berkaitan dengan penerimaan masyarakat terhadap suatu kebijakan atau program yang ditetapkan. Daya dukung masyarakat terhadap berbagai kebijakan atau program ditunjukkan oleh sikap responsif terhadap berbagai kebijakan yang ada. Sikap responsif positif yang dilakukan masyarakat dalam menjalankan kebijakan ditentukan oleh apakah kebijakan tersebut sesuai dengan kepentingan masyarakat atau tidak. Islamy (2007: 110) mengatakan bahwa "salah satu faktor penyebab orang tidak melaksanakan kebijakan karena kebijakan tersebut bertentangan dengan sistem nilai masyarakat" [6].

Implementasi Kebijakan Pariwisata Berbasis Kearifan Lokal di Kabupaten Manggarai Barat juga ditentukan bagaimana penerimaan masyarakat yang ditunjukkan dengan suatu sikap responsif terhadap kebijakan tersebut. Kondisi lingkungan sosial Kabupaten Manggarai Barat masih diwarnai dengan kentalnya budaya feodalistik yang membungkus sirkulasi kehidupan masyarakat. Imbasnya adalah hampir semua kebijakan di ranah publik didominasi oleh pihak pemerintah semata, termasuk kebijakan di bidang pariwisata. Masyarakat Kabupaten Manggarai Barat mengamini urusan kepariwisataan masuk dalam domain atau otoritas pemerintah daerah belaka. Kalaupun ada partisipasi dari masyarakat lokal, itu hanya menyentuh sisi luar saja. Porsi terbesar masih tetap digenggam oleh pihak pemerintah. Partisipasi masyarakat Manggarai Barat dalam aktivitas pariwisata berbasis kearifan lokal masih rendah. Hal ini disebabkan karena tingkat pemahaman masyarakat tentang pariwisata yang masih sangat terbatas. Hal ini dilatarbelakangi oleh tingkat pendidikan masyarakat Kabupaten Manggarai Barat yang rendah dan juga mayoritas masyarakat Kabupaten Manggarai Barat yang berkutat pada di bidang pertanian. Sehingga pada saat Pemerintah Kabupaten Manggarai Barat memproklamirkan pariwisata sebagai sektor utama dalam mengatrol pembangunan, masyarakat terkesan pasif bahkan apatis.

b. Kondisi Ekonomi

Faktor ekonomi juga turut menentukan berjalan optimal atau tidak sebuah implementasi kebijakan publik. Kondisi ekonomi di suatu wilayah yang menjadi tempat dilaksanakan kebijakan bisa mendukung ataupun menghambat implementasi kebijakan publik. Aktivitas pariwisata apapun modelnya tentu saja menyetuh kehidupan masyarakat baik langsung atau tidak. Hal serupa juga terjadi pada saat mengimplementasikan Kebijakan Pariwisata Berbasis Kearifan Lokal di Kabupaten Manggarai Barat. Salah satu faktor kunci bagi efektif tidaknya Implementasi Kebijakan Pariwisata Berbasis Kearifan Lokal di Kabupaten Manggarai Barat ditentukan oleh keberadaan faktor ekonomi di lingkungan dimana kebijakan tersebut dijalankan. Masyarakat kabupaten Manggarai Barat pada umumnya bermata pencarian sebagai petani, walaupun dari titik potensi yang dimiliki, semua 
wilayah yang ada di Kabupaten Manggarai Barat bisa dijadikan sebagai daerah pariwisata.

c. Kondisi Politik

Implementasi bersifat interaktif dari proses kegiatan yang mendahuluinya. Pada hakikatnya implementasi kebijakan tidak hanya sekadar proses administratif yang menerjemahkan suatu kebijakan ke dalam tindakan rutin administratif. Namun sekaligus sebagai proses politik yang melibatkan aneka konflik kepentingan. Dengan demikian, kualitas kebijakan tidak bisa dipandang semata-mata ditentukan oleh kinerja birokrasi, tetapi juga dipengaruhi oleh dimensi politik yang melingkupinya.

Dalam kaitannya dengan hal itu, situasi politik yang berkembang di Kabupaten Manggarai Barat tidak kondusif dalam mendukung efektivitas Implementasi Kebijakan Pariwisata Berbasis Kearifan Lokal. Kondisi politik di Kabupaten Manggarai Barat tidak kondusif ditandai dengan turbulensi politik di Kabupaten Manggarai Barat yang bermula pada saat Pemilihan Umum Kepala Daerah (Pemilukada) pada tahun 2010 silam. Hasil pemilukada sebagaimana yang ditetapkan oleh KPUD Kabupaten Manggarai Barat menetapkan bahwa pasangan Gusti Dulla dan Maximus Gasa sebagai Bupati dan Wakil Bupati Kabupaten Manggarai Barat periode 2011-2015. Akan tetapi keputusan KPUD Kabupaten Manggarai Barat tersebut ditolak oleh tiga pasangan calon sekaligus, yakni (a) pasangan calon Fidelis Pranda dan Pata Vinsensius, (b) Ardis Yosef dan Bernandus Barat Daya, dan (c) Antony Bagul Dagur dan Abdul Asis. Ketiga pasangan calon yang menolak tersebut melakukan banding ke Mahkamah Konstitusi (MK) pada tahun 2010. Akan tetap keputusan MK membatalkan semua esepsi yang disampaikan oleh pemohon tersebut (Risalah Keputusan MK Nomor 38/PHPU.DVIII/2010).

Persoalan mulai muncul ketika ada sebagian pihak terutama dari baris pendukung pasangan yang kalah yang berada di struktur birokrasi Pemerintah Kabupaten Manggarai Barat masih tetap menilai legitimasi yang digenggam Gusti Dulla dan Maximus Gasa inkonstitusional. Konsekuensinya adalah semua kebijakan di masa jabatan bupati dan wakil bupati di atas tidak legitimate (sah berdasarkan undang-undang), dengan demikian tidak patut untuk dijalankan. Ketidakmauan sebagian birokrat yang ada di tubuh pemerintahan Kabupaten Manggarai Barat terhadap setiap produk kebijakan yang dibuat oleh pimpinan daerah tentu saja menggangu jalannya implementasi kebijakan berjalan efektif demi tercapainya tujuan. Sebagaimana dalam studi administrasi publik, pendekatan yang paling awal dan banyak berpengaruh terhadap administrasi publik adalah pendekatan hukum (legalistic approach) dari suatu proses administrasi publik. Pendekatan ini mendasarkan diri pada asumsi bahwa pendekatan legal adalah kewenangan yang efektif [10]. Isu sentral dari pendekatan ini berkaitan dengan bagaimana menilai legitimasi dari suatu tindakan yang dilakukan oleh setiap lembaga atau pejabat administrasi publik. Sebab pada dasarnya bahwa setiap keputusan kebijakan harus memiliki payung hukum yang sah, dalam arti bahwa kebijakan tersebut dibuat oleh pejabat publik yang berwewenang, serta melalui prosedur yang sah telah tersedia. Keputusan kebijakan yang sah dapat mengikat para pegawai negeri (birokrat) untuk bertindak atau mengarahkan pilihan tindakan seperti yang telah diprogramkan. Wahab (2012: 25) mendefenisikan keputusan kebijakan sebagai "keputusan yang dibuat oleh pejabat pemerintahan untuk memberi keabsahan (legitimasi), kewenangan atau memberikan arahan terhadap pelaksanaan kebijakan publik".

\section{KESIMPULAN}

Berdasarkan hasil kajian yang sudah dipaparkan, maka terdapat beberapa kesimpulan yang dapat ditarik, yakni:

a. Implementasi Kebijakan Pariwisata di Kabupaten Manggarai Barat lebih cenderung menggunakan pendekatan top-down. Akibatnya ruang partisipasi bagi masyarakat sangat terbatas.

b. Jejaring dalam mempromosikan Pariwisata Berbasis Kearifan Lokal di Kabupaten Manggarai Barat sangat terbatas.

c. Kinerja implementator/agensi kebijakan belum optimal.

d. Terbatasnya kuantitas dan kualitas sumber daya manusia yang tersedia.

e. Ego sektoral yang masih sangat kuat, sehingga koordinasi dan komunikasi tidak berjalan efektif.

f. Lingkungan Sosial, Ekonomi, dan Politik yang membungkus sirkulasi kehidupan masyarakat di Kabupaten Manggarai Barat cenderung menghalangi terjadinya Implementasi Kebijakan efektif.

\section{DAFTAR PUSTAKA}

[1] Abdul Wahab, Solichin. 2012. Analisis Kebijakan Publik: Dari Formulasi Ke Penyusunan Model-Model Implementasi 
Kebijakan Publik", Cetak Pertama. Bumi Aksara. Jakarta

[2] Baiquini, dkk. 2010. Pariwisata Berkelanjutan dalam Pusaran Krisis Global. Edisi Pertama. Udayana Press. Bali.

[3] Creswell, John W. 2009. Research Design: Qualitative, Quantitative, and Mixed Methods Approaches. Third Edition Sage Publication. USA.

[4] Considine, Mark. 1994. Public Policy: A Critical Approach. First Published. University Of Melbourne. Australia.

[5] Gerston, Larry N. 1983. Making Public Policy: From Conflict to Resolution. First Edition. Scott, Foresman and Company. USA.

[6] Islamy, Irfan. 2007. Prinsip-prinsip Perumusan Kebijakan Negara. Cetakan Keempat Belas. Bumi Akasara. Jakarta.

[7] Kumorotomo, Wahyudi. 2009. Etika Administrasi Negara. Rajawali Pers. Jakarta.

[8] Madani, Muhlis. 2011. Dimensi Interaksi Aktor dalam Proses Perumusan Kebijakan Publik. Edisi Pertama. Graha Ilmu. Yogyakarta.

[9] Madiun, I Nyoman. 2010. Nusa Dua: Model Pengembangan Kawan Wisata Moderen. Udayana Press.

[10] Minarti, Lely Indah. 2007. Revolusi Administrasi Publik. Bayu Media. Malang.

[11] Newman, W. Laurence. 2000. Social research methods: Qualitative and Quantitative Approaches. Allyn dan Bacon. USA.

[12] Nugroho, Iwan. 2011. Ekowisata dan Pembangunan Berkelanjutan. Cetak Pertama. Pustaka Pelajar. Yogyakarta.

[13] Nugroho, Riant. 2011. Public Policy: Dinamika Kebijakan, Analisis Kebijakan, Manajemen Kebijakan. Edisi Revisi Ketiga. Media Komputindo. Jakarta.

[14] Peraturan Daerah Kabupaten Manggarai Barat Nomor 03 Tahun 2006 Tentang Dinas Kebudayaan dan Pariwisata.

[15] Peraturan Pemerintah Nomor 8 Tahun 2003 Tentang Pedoman Organisasi Perangkat Daerah.

[16] Peraturan Pemerintah Nomor 8 Tahun 2003 Tentang Pedoman Organisasi Perangkat Daerah.

[17] Pitana, I Gede dan Putu Gayatri. 2005. Sosiologi Pariwisata: Kajian Sosiologis Terhadap Struktur, Sistem dan Dampakdampak Pariwisata. Edisi Pertama. Andi. Yogjakarta.

[18] Rencana Strategis Badan Pengembangan Sumber Daya Kebudayaan dan Pariwisata 2011-2015.
[19] Rencana Induk Pengembangan Pariwisata Daerah Kabupaten Manggarai Barat tahun 2008.

[20] Risalah Sidang Pekara Nomor 38/PHPU.DVIII/2010 Perihal Permohonan Perselisihan Hasil Pemilihan Umum Kepala Daerah dan Wakil Kepala Daerah Kabupaten Manggarai Barat.

[21] Suharto, Edi. 2010. Kebijakan Sosial Sebagai Kebijakan Publik. Cetakan Ketiga. Alfabet. Bandung.

[22] Surat Pertanggunjawaban Pendapatan Fungsional Dinas Kebudayaan dan Pariwisata Tahun 2011.

[23] Suwena, I Ketut dan Widyatmaja, I Gusti. 2010. Pengetahuan Dasar IImu Pariwisata. Cetakan Pertama. Udayana Press. Bali.

[24] Undang-undang Republik Indonesia Nomor 08 Tahun 2003 Tentang Pembentukan Kabupaten Manggarai Barat Di Propinsi Nusa Tenggara Timur.

[25] Undang-undang Republik Indonesia Nomor 10 tahun 2009 tentang Kepariwisataan.

[26] Undang-undang Republik Indonesia Nomor 25 Tahun 2000 Tentang Program Pembangunan Nasional.

[27] Widiatedja, IGN Parekesit. 2011. Kebijakan Liberalisasi Pariwisata: Konstruksi Konsep, Ragam Masalah dan Alternatif Solusi. Cetakan Pertama. Udayana University Press. Bali.

[28] Widodo, Joko. 2011. Analisis Kebijakan Publik: Konsep dan Aplikasi Analisis Proses Kebijakan Publik. Edisi Pertama. Bayumedia. Malang 